\title{
Corporate Social Responsibility (CSR) Performance and Accrual Quality: Case study on Firms Listed on Indonesia Stock Exchange (IDX)
}

\author{
Ferry Aditya and Juniarti \\ Department of Accountancy-Faculty of Economics, Petra Christian University \\ E-mail: yunie@.petra.ac.id
}

Received: June 10, 2016 Accepted: July 2, 2016

doi:10.5296/ber.v6i2.9752 URL: http://dx.doi.org/10.5296/ber.v6i2.9752

\begin{abstract}
Research on the impact of corporate social responsibility (CSR) performance to the financial performance have been widely studied previously. However, there were a few studies investigate the effect of CSR on accrual quality which is one of the attributes of earning quality. The aim of this study is to examine the affect of CSR toward accrual quality in the context of Indonesia, where the empirical results of the benefits of CSR implementation are still scant.

Research samples are all listed companies in Indonesia Stock Exchange (IDX) in miscellaneous industry sector for period 2009 to 2013. There are 92 firm years included in this study. CSR is measured by scoring CSR activities of the firm based on GRI Index guideline version 3.1, whereas attributes of earning quality used in this study is accrual quality. We include two control variables in this research model i.e. firm size and leverage.

The results show that CSR performance do not explain the changes in accrual quality. Leverage has no effect on accrual quality as well. On the other hand firm size has a significant effect on CSR performance however the sign of association is contrary with the expected.
\end{abstract}

Keywords: Corporate social responsibility, Earning quality, Accrual quality

\section{Introduction}

The failure of several big companies such as Enron Corporation, Arthur Anderson, Lehman Brotthers, and worldCom have diminished public trust (Snider et al., 2003). The business disaster including financial scandals have triggered the need of strong corporate social responsibility (CSR). Yoon et al. (2006) said that CSR activities can be used to attract consumer social view attention to the firms, to create firms's brand image and to develop positive relationships with stakeholders as well. Stakeholders will use information provided 
by companies to make decision. According to Hong \& Andersen (2011), external stakeholders will rely on financial statement to value amount, timing, and uncertainty of future cash flow. Therefore, the quality of reported earning has an important role in communication process between firms and its external stakeholders.

There are only a few research that investigate CSR and earning quality, beside that the results of prior research still vary. Some of previous research showed the positive relationshiop between CSR and erning quality, whereas others found the negative association of CSR and eaning quality (Belkaoui, 2004; Laksmana \& Yang, 2009; Muttakin et al., 2015, Salewski \& Zulch, 2014). Moreover research topic that had been studied for many times is about the affect of CSR on financial performance (Mc Guire et al., 1988; Preston \& O'Bannon, 1997; Waddock \& Graves, 1997; Balabanis et al., 1998; Stanwick \& Stanwick, 1998; Mc Williams \& Siegel, 2000; Moore, 2001; Van de Velde et al., 2005; Fauzi \& Idris, 2009; Rais \& Goedegebuure, 2009; Dunn \& Sainty, 2009; Aras et al., 2010; Karagiorgos, 2010; Reddy \& Gordon, 2010; Samy et al., 2010; Crisostomo et al., 2011; Ekatah et al., 2011; Saleh et al., 2011; Bayoud et al., 2012; Luethge \& Han, 2012; Amrousy et al., 2012; Sun, 2012; Purnomo \& Widianingsih, 2012; Afiff \& Anantadjaya, 2013; Nuryaman, 2013; Turcsanyi \& Sisaye, 2013; Dewi et al., 2014; Malik \& Nadeem, 2014; Chih \& Chih, 2014; Chen et al., 2015).

There is a theory which can be used to explain the affect of CSR on eaning quality, which is stakeholder theory. Freeman (1984) in Mainardes et al. (2011) explained that firm, toward stakeholder, not only responsible in economic aspect but also in moral aspect (social and environment). CSR is considered as embodiment of stakeholder theory, because it can fulfill social, economic, and environment responsibility (Caroll, 1991). Based on previous statement, then firm that do CSR will be more responsible economically and morally. Responsible in moral aspect means that firm will reported earning based on reality and transparent, therefore the firm financial statement will be reliable and represent faithfulness.

Based on stakeholder theory, positive relationship between CSR and earning quality needs to be reviewed. Moreover, the results of research conducted by Laksmana \& Yang (2009) has also inspired this study. We intend to prove positive relationship between CSR and earning quality proxied by accrual quality on miscellaneous industry firm hich-listed on Indonesia Stock Exchange (IDX).

\section{Theoretical Foundation and Hypothesis Development}

\subsection{Theoretical Foundation}

\subsubsection{Stakeholder Theory}

Stakeholder theory first emerged from Freeman's idea (1984) written in his article, Strategic Management: a Stakeholder Approach (Mainardes et al., 2011). Freeman (1984) in Pirsch et al. (2007) defined stakeholders as group or individual that affect and affected by firm's goal achievement.

Based on normative aspect, stakeholder theory is viewed as the guidance of firm, so that firm can do its business activities based on moral principle (Donaldson \& Preston, 1995). This 
statement is supported by Pirsch et al. (2007). They stated that firm continuity and success depend on fulfillment of economic (profit maximization) and non-economic (social and environment) responsibility by fulfilling various needs of stakeholder.

Clarkson (1995) divides stakeholder into two groups, they are primary stakeholder and secondary stakeholder. Primary stakeholder is stakeholder which have formal contract with firm, for example: shareholder, employee, and vendor. Without continuous participation from primary stakeholder, firm can't continue it's operation. Secondary stakeholder is stakeholder which affect or affected by firms, but does not involve in firms business activity, i.e society, government, and mass media as well.

Friedman \& Miles (2006) in Mainardes et al. (2011) divide those group using three approach, they are: descriptive, instrumental, and normative. (1) Descriptive approach used to manage how firm operate and manage stakeholder; (2) Instrumental approach used to show how firm achieve organization goal through stakeholder management; (3) Normative approach used to define how firm should operate in business, especially when related with moral principle..

Choi \& Wang (2009) stated that good relationship with stakeholder can give value-added to firm, such as improvement in employee's motivation to achieve firm's goal; growth on consumer's demand; and transfer knowledge from vendor to firm.

\subsubsection{Corporate Social Responsibility (CSR)}

According to Marsden (2001), CSR is considered as the core of companies' behavior and responsibility to their total impact on the societies, it can be positive or negative impact toward economic, social, and environment. Carroll (1991) said that firms which do CSR do not operate only for profit, but also fulfill moral responsibility toward stakeholders, such as obeying the law, behaving ethically, and being a good firm.

Porter \& Kramer (2006) identified that there are four reasons to do CSR activities. First, society and many companies believed that actually firms have moral responsibility to fulfill stakeholder's need. Second, going concern concept drives firm to care its social and environmental. Third, the license to operate. Governments, community, and other parties provide firms implicit and explicit permission to do their business. Finally, firms expect to achieve reputation through the CSR activities.

In line with the above reasons, Porter \& Kramer (2006) stated that CSR will improve firm's image, strengthen firm's brand, and enliven firm's morale. Hong \& Andersen (2010) argue that the more socially responsible firms, the higher the earning quality they produced. In addition, socially responsible firms will avoid activities to manage earnings.

\subsubsection{Accrual Quality}

Accrual is underlying the recording of transactions or events in which revenues and expenses recorded at the time in which the transaction occurs rather than when payment is made or cash received (Warren et al., 1998). Dechow \& Dichev (2002) said that accrual quality can be determined by looking how close of firm's earning and firm's cash. Previous research stated uncovered that firms will have better earning quality, if their accrual quality is high too, are: 
Penman (2001), Dechow \& Dichev (2002).

\subsubsection{Firm Size}

Aryani (2011) said that firm size is a measurement to categorize size of the firm. There are several method to measure firm size according to Waddock \& Graves (1997): total sales, total asset, and total employee. Firm size is important in this research, because usually firm with small size can't do CSR activity (Karagiorgos, 2010). This control variable used to minimize the significant gap between big firm and small firm, so total asset can be distributed normally (Sari, 2012).

\subsubsection{Leverage}

Sari (2012) said that leverage is considered as firm's financial risk because it can be used to describe firm's equity structure and to detect risk of uncollectable debt. This research used debt to asset ratio to measure firm's leverage, as done by Prior et al. (2008), Sun (2012), and Muttakin et al. (2015). Debt to asset ratio is a ratio to measure firm's asset which financed by debt. If the value of DAR is higher, it's also indicate the higher interest expense that firm will paid.

\subsection{Hypothesis Development}

\subsubsection{The Affect of CSR on Accrual Quality}

Stakeholder theory is a theory which give guidance for firm, so that firm can do its's business activity based on moral principle (Donaldson \& Preston, 1995). This statement is supported by Pirsch et al. (2007). They said that firm have to fulfill stakeholder's need, both economic and non-economic, in order to guarantee it's continuity and success. Caroll (1991) stated that CSR is considered as embodiment of stakeholder theory, because it can fulfill social, economic, and environment responsibility.

CSR is considered as embodiment of stakeholder theory, therefore firm which applying CSR will be more responsible economically and non-economically based on moral principle. Moral principle will make firm do the right things to do, such as: obeying the rule, acting based on ethics, and becoming good firms

It can be said that firms which applying CSR will have higher accrual quality compared to firms which not applying CSR, because those firm which applying CSR obeyed financial accounting standard based on moral principle. This statement is supported by Belkaoui (2004), Laksmana and Yang (2009), Kim et al. (2011), and Muttakin et al. (2015). From statements above, we hypothesize :

H1: Corporate social responsibilty positively affect accrual quality.

\subsubsection{The Affect of Firm Size on Accrual Quality}

Firm size is kind of control variable which usually used in research that related with firm's profit. Cowen et al. (1987) in Sembiring (2006) stated that bigger firm had bigger operating activity and influence toward stakeholder, so firm will try to maintain relationship with 
stakeholder. Bigger firm will be more stable, had more predictable operations, and fewer estimated error (Dechow \& Dichev, 2002), therefore bigger firm tend to have better accrual quality. (Francis et al., 2004; Francis et al., 2005; Sembiring, 2006; Laksmana \& Yang, 2009). From statements above, we hypothesize :

H2: Firm size positvely affect accrual quality.

\subsubsection{The Affect of Leverage on Accrual Quality}

Firm needs investment from market in order to survive and develop it's business. There are a lot of ways for firm to get fund for purchasing, production, selling, and paying expenses, for example debt financing (Valipour \& Moradbeygi, 2011). The higher leverage score, the higher firm's assets financed using debt and the higher firm's solvability risk. Valipour \& Moradbeygi (2011) concluded that higher debt financing, will lead to aggresive accrual policy by management to manage income. This policy used by management so that their firm will not violate debt covenant. This statement is supported by Francis et al. (2005), Ghosh \& Moon (2010), Valipour \& Moradbeygi (2011), Kim et al. (2011) and Fung \& Goodwin (2013). From statements above, we hypothesize :

H3: Leverage negatively affect accrual quality.

\section{Research Method}

Independent variable in this research is CSR, and the dependent variable is accrual quality. Meanwhile, the control variables are firm size and leverage. Here is an operational definitions of each variables:

\section{i. Accrual Quality}

Accrual quality is how close firm's earning with firm's cash. This research measure accrual quality based on Dechow \& Dichev (2002). ACCQUAL is the standard deviation of residuals $\left(\varepsilon_{\mathrm{i}}\right)$ from the following regression:

$$
T C A_{i, t}=y_{0}+y_{1} C F O_{i, t-1}+y_{2} C F O_{i_{i}, t}+y_{a} C F O_{i, t+1}+\varepsilon_{i, t}
$$

Large values of ACCQUAL indicate lower accrual quality.

\section{ii. CSRi}

CSR Variable measured using GRI Index 3.1, There are 84 criteria, including economic, social, and environmental dimension. If firm reported CSR we will give a score, but if a firm didn't report CSR we will give zero. Those score will be summed then subtracted with number of criterias in GRI 3.1. This measurement also used in Jenkins \& Yakovleva (2006), Yuliana et al. (2008); Panayiotou et al. (2009), Mulyadi \& Anwar (2012), Waworuntu et al. (2014).

$$
\text { CSRi }=\frac{\text { Total firm's disclosures }}{\text { Total criteria of G3.1 }}
$$




\section{Macrothink}

The higher CSR score, indicate that more firm's CSR activity fulfil GRI's criteria.

\section{iii. Firm Size}

Firm size is measurement that used for categorize the size of the firm (Aryani, 2011).

Firm size can be calculated by log total asset, as done by Chih et al. (2008), Sun (2012), and Bayoud et al. (2012).

\section{FSIZE $=\log ($ total assets $)$}

\section{iv. Leverage}

To measure firm's leverage, this research used debt to asset ratio, as is done by Prior et al. (2008), Sun (2012), and Muttakin et al. (2015). Firm's total debt consist by short term and long term debt. The component of short term debt are: bank overdrafts, short term debts and borrowings, short term portion of long term borrowings, current obligations under finance leases and interest bearings loan. Meanwhile, the component of long term debt are: bonds, loans, mortgage debts, sinking funds, finance lease obligations and long term bank overdrafts (Welch, 2011). Higher leverage value also indicate the higher interest expense that firm will pay. Leverage calculated as follow:

$$
\text { Debt to Asset Ratio }=\frac{\text { Total debt }}{\text { Total asset }}
$$

This research used two kinds of data, they are quantitative and qualitative. Quantitative data in this research, such as: operating income, current asset, current liabilities, cash and cash equivalent, short term debt, depreciation and amortization expense, total assets, and total debt, are collected from Bloomberg. Meanwhile, qualitative data in this research is CSR activity which reported on firm's annual report. Firm's annual reports are collected from firm's website and Indonesian Stock Exchange (IDC).

This study applies the purposive sampling method to select sample. Purposive sampling is sampling method that choose population which fulfil research criterias. The sample criteria are as follows: (1) Firms in miscellaneous industry sector which issue annual report for the period 2009 to 2013; (2) Firms have already listed on Indonesia Stock Exchange (IDX) before 2009; (3) Firms have a complete annual report during the period of investigation.

\section{Results}

\subsection{Descriptive Statistics}

Sample profiles in this research are presented in Table 1.

Table1. Descriptive Statistics

\begin{tabular}{|l|l|r|r|c|r|}
\hline & $\mathrm{N}$ & Minimum & Maximum & Mean & Std. Deviation \\
\hline ACCQUAL & 92 & .00000 & .91900 & .1150870 & .18484646 \\
\hline CSRi & 92 & .08300 & .38100 & .2132500 & .06594764 \\
\hline FSIZE & 92 & 10.94000 & 14.26000 & 12.1584783 & .65266139 \\
\hline
\end{tabular}




\begin{tabular}{|l|l|l|l|l|l|}
\hline LEV & 92 & .00000 & 2.06800 & .3835435 & .38617221 \\
\hline Valid N (listwise) & 92 & & & & \\
\hline
\end{tabular}

ACCQUAL has relatively low value. Smaller value is prefer since it shows higher quality of accrual. CSRi as the interest variable in this research has quite low of mean value. On average, only $21 \%$ of CSR activities of the sample firms comply with the GRI guideline. FSIZE of the sample firms is quite varied, it can be seen from the range between min and max value is wide. LEV that represents company's risk has mean as of 0,38 . It can be implied that on average, samples have a moderate risk, since only $38 \%$ of their assets are contributed by debt.

This research do four kinds of classical assumption test, they are normality test, autocorrelation test, heteroscedasticity test, and multicollinearity test. Test of classical assumption is required to prove that data fit with the regression model. After several tests performed to overcome the normality problem in the regression model, the classical assumption is satisfy. Normality test is justified as shown by significant value of Kolmogorov-Smirnov as of 0,092 greater than signficant level at 0,05. This model also free from autocorrelation problem. Durbin Watson value is 1,935 located between dU 1,7176 and (4-dU) 2,284, therefore autocorrelation test is passed. Glejser test shows that all variables have significant value greater than 0,05 so it can be concluded that regression model is free from heteroskedasticity problem. There is no multicollinearity problem in the regression model, since all variable have VIF greater than 10 and have TOL smaller than 0,05

\subsection{Goodness of Fit Test}

After classical assumption test, then we do feasibility test of regression model to show that regression model is decent to test the hypothesis.

This research uses two indicators to test the godness of fit of regression model that is F-test and coefficient determination. F-test is as of 4,963 and has a significant value 0,003 , less than significant value 0,05 it means that all of independent variables significantly affect dependent variable and regression model is decent to test the hypothesis.

Table 2. F-test

\begin{tabular}{|l|r|r|r|r|c|c|}
\hline \multicolumn{2}{|l|}{ Model } & Sum of Squares & df & Mean Square & F & Sig. \\
\hline \multirow{2}{*}{1} & Regression & 3.717 & 3 & 1.239 & 4.963 & $.003^{\mathrm{b}}$ \\
\cline { 2 - 7 } & Residual & 19.473 & 78 & .250 & & \\
\cline { 2 - 7 } & Total & 23.190 & 81 & & & \\
\hline
\end{tabular}

In addition, adjusted $\mathrm{R}^{2}$ is 0,128 mean that as of $12,8 \%$ changes in dependent variable can be explained by all independent variables. 
Table 3. Coefficient of Determination

\begin{tabular}{|l|c|r|r|r|r|}
\hline Model & $\mathrm{R}$ & $\mathrm{R}$ Square & Adjusted R Square & Std. Error of the Estimate & Durbin-Watson \\
\hline 1 & $.400^{\mathrm{a}}$ & .160 & .128 & .49965 & 1.935 \\
\hline \multicolumn{7}{|l|}{ a. Predictors: (Constant), LEV, CSRi, FSIZE } \\
\hline
\end{tabular}

\subsection{Hypothesis Test}

To test the hypothesis this research used t-test, the following are the results of t-test:

Table 4. T-test

\begin{tabular}{|c|c|c|c|c|c|c|}
\hline \multirow{2}{*}{\multicolumn{2}{|c|}{ Model }} & \multicolumn{2}{|c|}{ Unstandardized Coefficients } & \multirow{2}{*}{$\begin{array}{c}\text { Standardized Coefficients } \\
\text { Beta } \\
\end{array}$} & \multirow[b]{2}{*}{$\mathrm{t}$} & \multirow[b]{2}{*}{ Sig. } \\
\hline & & B & Std. Error & & & \\
\hline \multirow[t]{4}{*}{1} & (Constant) & 2.382 & 1.125 & & 2.118 & .037 \\
\hline & CSRi & .356 & .951 & .045 & .375 & .709 \\
\hline & FSIZE & -.318 & .095 & -.401 & -3.349 & .001 \\
\hline & LEV & .057 & .154 & .042 & .368 & .714 \\
\hline
\end{tabular}

Table 4 shows that CSR has a positive sign as predicted, however this coefficient is not significant at significance level of 0,05 . It is implied that CSR has no significant effect in changes of accrual quality. FSIZE has a significance value less than significance level 0,05, unfortunately the sign of the coefficient differ than expected. It also means that hypothesis 2 is not accepted. The bigger the company size, the lower the quality of accrual. The third hypothesis in this research is also not proven. Eventhough the sign of LEV as predicted, but the association is not significant since the significance value is greater that significance level at 0,05 .

\section{Conclusion}

This research aimed to prove the existence of positive affect from corporate social responsibility (CSR) to earning quality proxied by accrual quality in miscellaneous industry firm listed on IDX. This research found that CSR didn't affect accrual quality, so H1 is rejected. This happened because, based on Indonesian Ministry of Environment and Forestry, hotel, fish processing, hospital, mining sector, and palm plantations have a big role in polluting and harming environment. So another sector from previous statement, including miscellaneous industry sector, which is our focus of research, will do CSR only to comply goverment regulation as formality not morality. This finding is consistent with Kurniawan \& Wibowo (2009) who stated that there is no relationship between CSR and discretionary accrual.

Based on this research findings, firm size negatively and significantly affect accrual quality, so H2 is rejected. This finding consistent with Llukani (2013) who found that both big firm and small firm will do earning management to avoid loss and earning decrease. Rangan (1998) stated that in bigger firm, management tend to modify current accrual in order to increase firm's earning. Therefore the firm's accrual quality will be lower. 
Lastly, leverage does not affect accrual quality. This finding consistent with Gray et al. (2009) who found that leverage didn't affect accrual quality because most of firm equity come from private debt, not public debt. Triningtyas \& Siregar (2014) stated that only $24,74 \%$ from total firm listed in IDX financed from public debt. So, majority Indonesian firm financed from private debt, therefore private lenders will have easier access to firm's business and financial information, and also have right to monitor management, so that management can't used accrual policy to manage earning, because private lenders knows firm's real situation.

\section{References}

Afiff, S., \& Anantadjaya, S. (2013). CSR \& Performance: Any Evidence from Indonesian LQ45? Review of Integrative Business \& Economics Research, 2(1), 85-101.

Amrousy, Z., Gavious, I., Katz, H., \& Yosef, R. (2012). Corporate Social Responsibility (CSR) and Firm Performance. Journal of Modern Accounting and Auditing, 8(11), 1691-1703.

Aras, G., Aybars, A., \& Kutlu, O. (2010). Investigating The Relationship between Corporate Social Responsibility and Financial Performance in Emerging Market. International Journal of Productivity and Performance Management, 59(3), 229-254. http://dx.doi.org/10.1108/17410401011023573

Aryani, D. S. (2011). Manajemen Laba Pada Perusahaan Manufaktur di Bursa Efek Indonesia. Jurnal Ekonomi dan Informasi Akuntansi, 1(2), 200-220.

Balabanis, G., Philips, H. C., \& Lyall, J. (1998). Corporate Social Responsibility and Economic Performance in The Top British Companies: Are They Linked? European Business Review, 98(1), 25-44. http://dx.doi.org/10.1108/09555349810195529

Bayoud, N. S., Kavanagh, M., \& Slaughter, G. (2012). An Empirical Study of The Relationship Between Corporate Social Responsibility Disclosure and Organizational Performance: Evidence From Libya. International Journal of Management and Marketing Research, 5(3), 69-82.

Belkaoui, A. R. (2004). The Impact of Corporate Social Responsibility on The Informativeness of Earnings and Accounting Choices. Advances in Environmental Accounting and Management, 2, 121-136. http://dx.doi.org/10.1016/S1479-3598(03)02005-3

Carroll, A. B. (1991). The Pyramid of Corporation Social Responsibility: Toward the Moral Management of Organizational Stakeholder. Business Horizons, 34(4), 39-48. http://dx.doi.org/10.1016/0007-6813(91)90005-G

Chen, L., Feldmann, A., \& Tang, O. (2015). The Relationship between Disclosures of Corporate Social Performance and Financial Performance: Evidences from GRI Reports in Manufacturing Industry. International Journal of Production Economics, 170(B), 445-456. http://dx.doi.org/10.1016/j.ijpe.2015.04.004

Chih, H., \& Chih, H. (2014). Doing Good With or Without Being Known? Media Coverage of Corporate Social Performance and Its Impact on Corporate Financial Performance. 
Managerial Finance, 40(9), 883-902. http://dx.doi.org/10.1108/MF-10-2013-0305

Choi, J., \& Wang, H. (2009). Stakeholder Relations and The Persistence of Corporate Financial Performance. Strategic Management Journal, 30, 895-907. http://dx.doi.org/10.1002/smj.759

Clarkson, M. B. (1995). A Stakeholder Framework for Analyzing and Evaluating Corporate Social Performance. Academy of Management Review, 20(1), 92-117.

Crisostomo, V. L., Freire, F. S., \& Cortes de Vasconcellos, F. (2011). Corporate Social Responsibility, Firm Value, and Financial Performance in Brazil. Social Responsibility Journal, 6, 295-309. http://dx.doi.org/10.1108/17471111111141549

Dechow, P. M., \& Dichev, I. D. (2002). The Quality of Accruals and Earnings: The Role of Accrual Estimation Errors. The Accounting Review, 77, 35-59. http://dx.doi.org/10.2308/accr.2002.77.s-1.35

Dewi, D. M., Sudarma, M., Djumahir, \& Ganis, E. (2014). CSR Effect on Market and Financial Performance. International Journal of Business and Management Invention, 3(1), 56-66. http://dx.doi.org/10.18860/ed.v1i02.2525

Donaldson, T., \& Preston, L. E. (1995). The Stakeholder Theory of the Corporation: Concepts, Evidence, and Implications. The Academy of Management Review, 20(1), 65-91.

Dunn, P., \& Sainty, B. (2009). The Relationship among Board of Director Characteristics, Corporate Social Performance and Corporate Financial Performance. International Journal of Managerial Finance, 5(4), 407-423. http://dx.doi.org/10.1108/17439130910987558

Ekatah, I., Samy, M., Bampton , R., \& Halabi, A. (2011). The Relationship Between Corporate Social Responsibility and Profitability: The Case of Royal Dutch Shell Plc. Corporate Reputation Review, 14(4), 249-261. http://dx.doi.org/10.1057/crr.2011.22

Fauzi, H., \& Idris, K. M. (2009). The Relationship of CSR and Financial Performance: New Evidence from Indonesian Companies. Issues in Social and Environmental Accounting, 3(1), 66-87.

Francis, J., LaFond, R., Olsson, P. M., \& Schipper, K. (2004). Cost of Equity and Earning Attributes. The Accounting Review, 79(4), 967-1010. http://dx.doi.org/10.2308/accr.2004.79.4.967

Francis, J., LaFond, R., Olsson, P., \& Schipper, K. (2005). The Market Pricing of Accruals Quality. Journal of Accounting and Economics 39, 295-327. http://dx.doi.org/10.1016/j.jacceco.2004.06.003

Fung, S. Y., \& Goodwin, J. (2013). Short-term Debt Maturity, Monitoring and Accruals-based Earning Management. Journal of Contemporary Accounting \& Economics, 9(1), 67-82. http://dx.doi.org/10.1016/j.jcae.2013.01.002

Ghosh, A., \& Moon, D. (2010). Corporate Debt Financing and Earning Quality. Journal of Business Finance \& Accounting, 37(5) \& $\quad$ (6), 538-559. 
http://dx.doi.org/10.1111/j.1468-5957.2010.02194.x

Global Reporting Initiative. (2000-2011). Sustainability Reporting Guidelines. Retrieved October 23, 2015, from https://www.globalreporting.org/resourcelibrary/G3.1-Guidelines-Incl-Technical-Protocol.pdf Gray, P., Koh, P. S., \& Tong, Y. H. (2009). Accruals Quality, Information Risk and Cost of Capital: Evidence from Australia. Journal of Business Finance \& Accounting, 36(1) \& (2), 51-72. http://dx.doi.org/10.1111/j.1468-5957.2008.02118.x

Hong, Y., \& Andersen, M. L. (2011). The Relationship Between Corporate Social Responsibility and Earnings Management: An Exploratory Study. Journal of Business Ethics, 104(4), 461-471. http://dx.doi.org/10.1007/s10551-011-0921-y

Jenkins, H., \& Yakovleva, N. (2006). Corporate Social Responsibility in The Mining Industry: Exploring Trends in Social and Environmental Disclosure. Journal of Cleaner Production, 14, 271-284. http://dx.doi.org/10.1016/j.jclepro.2004.10.004

Karagiorgos, T. (2010). Corporate Social Responsibility and Financial Performance: An Empirical Analysis on Greek Companies. European Research Studies 13(4), 85-108.

Kim, Y., Park, M. S., \& Wier, B. (2011). Is Earning Quality Associated with Coporate Social Responsibility? Accounting Review, Forthcoming, 1-51.

Kurniawan, M., \& Wibowo, D. H. (2009). Analysis on Accounting Conservatism and CSR Disclosures of Indonesian Banks Listed on IDX from 2004 to 2007. Journal of Applied Finance and Accounting, 2(2), 13-30.

Laksmana, I., \& Yang, Y. (2009). Corporate Citizenship and Earnings Attributes. Advanes in International Accounting, 25, 40-48. http://dx.doi.org/10.1016/j.adiac.2009.02.001

Llukani, T. (2013). Earning Management and Firm Size: An Empirical Analyze in Albanian Market. European Scientific Journal, 9(16), 135-143.

Luethge, D., \& Han, H. G. (2012). Assesing Corporate Social and Financial Performance in China. Social Responsibility Journal, $\quad 8(3), \quad 389-403$. http://dx.doi.org/10.1108/17471111211247965

Mainardes, E. W., Alves, H., \& Raposo, M. (2011). Stakeholder Theory: Issues to Resolve. Management Decision, 49(2), 226-252. http://dx.doi.org/10.1108/00251741111109133

Malik, M. S., \& Nadeem, M. (2014). Impact of Corporate Social Responsibility on The Financial Performance of Banks in Pakistan. International Letters of Social and Humanistic Sciences, 21, 9-19. http://dx.doi.org/10.18052/www.scipress.com/ILSHS.21.9

Marsden , C. (2001). The Role of Public Authorities in Corporate Social Responsibility. Retrieved from Agence Alter website: http://www. alter. be/socialresponsibility/people/marchri/en/displayPerson

McGuire, J. B., Sundgren, A., \& Schneeweis, T. (1988). Corporate Social Responsibility and 
Firm Financial Performance. The Academy of Management Journal, 31(4), 854-872. http://dx.doi.org/10.2307/256342

McWilliams, A., \& Siegel, D. (2000). Corporate Social Responsibility and Financial Performance: Correlation or Misspesification? Strategic Management Journal, 21(5), 603-609.

http://dx.doi.org/10.1002/(SICI)1097-0266(200005)21:5<603::AID-SMJ101>3.0.CO;2-3

Moore, G. (2001). Corporate Social and Financial Performance: An Investigation in the U.K. Supermarket Industry. Journal of Business Ethics 34, 299-315. http://dx.doi.org/10.1023/A:1012537016969

Mulyadi, M. S., \& Anwar, Y. (2012). Impact of Corporate Social Responsibility toward Firm Value and Profitability. The Business Review, Cambridge, 19(2), 316-322.

Muttakin, M. B., Khan, A., \& Azim, M. I. (2015). Corporate Social Responsibility Disclosures and Earning Quality: Are They a Reflection on Managers' Opportunistic Behavior? Managerial Auditing Journal, 30(3), 277-298. http://dx.doi.org/10.1108/MAJ-02-2014-0997

Nuryaman. (2013). The Effect of Corporate Social Responsibility Activities on Profitability and Stock Price (Studies on The companies listed on Indonesia Stock Exchange). Journal of Global Management, 6(1).

Panayiotou, N. A., Aravossis, K. G., \& Moschou, P. (2009). A New Methodology Approach for Measuring Corporate Social Responsibiity Performance. Water Air Soil Pollat: Focus 9, 129-138. http://dx.doi.org/10.1007/s11267-008-9204-8

Penman, S. H. (2001). Financial Statement Analysis and Security Valuation. New York: McGraw-Hill/Irwin.

Pirsch, J., Gupta, S., \& Grau, S. L. (2007). A Framework for Understanding Corporate Social Responsibility Programs as a Continuum: An Exploratory Study. Journal of Business Ethics, 70, 125-140. http://dx.doi.org/10.1007/s10551-006-9100-y

Porter, M. E., \& Kramer, M. R. (2006). The Link Between Competitive Advantage and Corporate Social Responsibility. Harvard Business Review, 84(12), 78-92.

Preston, L. E., \& O'Bannon, D. P. (1997). The Corporate Social-Financial Performance $\begin{array}{llll}\text { Relationship. Business } \quad \text { and } & \text { Society, } & \text { 36(4), }\end{array}$ http://dx.doi.org/10.1177/000765039703600406

Prior, D., Surroca, J., \& Tribo, J. A. (2008). Are Socially Responsible Managers Really Ethical? Exploring the Relationship Between Earnings Management and Corporate Social Responsibility. Corporate Governance: An International Review, 16(3), 160-177. http://dx.doi.org/10.1111/j.1467-8683.2008.00678.x

Purnomo, P. K., \& Widianingsih, L. P. (2012). The Influence of Environmental Performance on Financial Performance with Corporate Social Responsibility (CSR) Disclosure as a 


\section{Al Macrothink}

Business and Economic Research ISSN 2162-4860 2016, Vol. 6, No. 2

Moderating Variable: Evidence from Listed Companies in Indonesia. Review of Integrative Business and Economics Research, 1(1), 57-69.

Rais, S., \& Goedegebuure, R. V. (2009). Corporate Social Performance and Financial Performance. The Case of Indonesian Firms in The Manufacturing Industry. Problems and Perspectives in Management, 7(1), 224-237.

Rangan, S. (1998). Earning Management and The Performance of Seasoned Equity Offerings. $\begin{array}{lllll}\text { Journal of Financial } & \text { Economics, } & \text { 50, }\end{array}$ http://dx.doi.org/10.1016/S0304-405X(98)00033-6

Reddy, K., \& Gordon, L. W. (2010). The Effect of Sustainability Reporting on Financial Performance: An Empirical Study Using Listed Companies. Journal of Asia Entrepreneurship and Sustainability, 6(2), 19-42.

Saleh, M., Zulkifli , N., \& Muhamad, R. (2011). Looking for Evidence of Relationship between Corporate Social Responsibility and Corporate Social Financial Performance in An Emerging Market. Asia-Pacific Journal of Business, 3(2), 165-190. http://dx.doi.org/10.1108/17574321111169849

Salewski, M., \& Zulch, H. (2014). The Association between Corporate Social Responsibility (CSR) and Earnings Quality-Evidence from European Blue Chips. HHL Working Paper Series, 112.

Samy, M., Odemilin, G., \& Bampton, R. (2010). Corporate Social Responsibility: A Strategy for Sustainable Business Success. An Analysis of 20 Selected British Companies. Corporate Governance: The international journal of business in society, 10(2), 203-217. http://dx.doi.org/10.1108/14720701011035710

Sari, R. A. (2012). Pengaruh Karakteristik Perusahaan Terhadap Corporate Social Responsibility Disclosures pada Perusahaan Manufaktur yang Terdaftar di Bursa Efek Indonesia. Jurnal Nominal, 1(1), 124-140.

Sembiring, E. R. (2006). Karakteristik Perusahaan dan Pengungkapan Tanggung Jawab Sosial: Study Empiris pada Perusahaan yang Tercatat di Bursa Efek Jakarta. Jurnal MAKSI, 6(1), 69-85.

Snider, J., Hill, R. P., \& Martin, D. (2003). Corporate Social Responsibility in the 21st Century: A View from the World's Most Sucessful Firms. Journal of Business Ethics, 48, 175-187. http://dx.doi.org/10.1023/B:BUSI.0000004606.29523.db

Stanwick, P. A., \& Stanwick, S. D. (1998). The Relationship between Corporate Social Performance, and Organizational Size, Financial Performance, and Environmental Performance: An Empirial Examination. Journal of Business Ethics, 17(2), 195-204. http://dx.doi.org/10.1023/A:1005784421547

Sun, L. (2012). Further Evidence on The Association between Corporate Social Responsibility and Financial Performance. International Journal of Law and Management, 54(6), 472-484. http://dx.doi.org/10.1108/17542431211281954 


\section{Macrothink}

Business and Economic Research ISSN 2162-4860 2016, Vol. 6, No. 2

Triningtyas, I. A., \& Siregar, S. V. (2014). Pengaruh Kualitas Akrual Terhadap Biaya Utang dan Biaya Ekuitas: Studi pada Perusahaan yang Terdaftar di Bursa Efek Indonesia Tahun 2005-2011. Conference: Simposium Nasional Akuntansi (SNA), 1-22.

Turcsanyi, J., \& Sisaye, S. (2013). Corporate Social Responsibility and Its Link to Financial Performance. World Journal of Science, Technology and Sustainable Development, 10(1), 4-18. http://dx.doi.org/10.1108/20425941311313065

Valipour, H., \& Moradbeygi, M. (2011). Corporate Debt Financing and Earnings Quality. Journal of Applied Finance \& Banking, 1(3), 139-157.

Van de Velde, E., Vermeir, W., \& Corten , F. (2005). Corporate Social Responsibility and Financial Performance. Corporate Governance: The international journal of business in society, 5(3), 129-138. http://dx.doi.org/10.1108/14720700510604760

Waddock, S. A., \& Graves, S. B. (1997). The Corporate Social Performance--Financial Performance Link. Strategic Management Journal, 18(4), 303-319. http://dx.doi.org/10.1002/(SICI)1097-0266(199704)18:4<303::AID-SMJ869>3.0.CO;2-G

Warren, C. S., Reeve, J. M., \& Fess, P. E. (1999). Accounting. Ohio: International Thomson Publishing.

Waworuntu, S. R., Wantah, M. D., \& Rusmanto, T. (2014). Corporate Social Responsibility and Financial Performance Analysis: Evidence from Top ASEAN Listed Companies. $\begin{array}{llll}\text { Procedia-Social } \text { and } & \text { Behavioral } & \text { Science, } & \text { 164, }\end{array}$ http://dx.doi.org/10.1016/j.sbspro.2014.11.107

Welch, I. (2011). Two Common Problems in Capital Structure Research: The Financial-Debt-To-Asset Ratio and Issuing Activity Versus Leverage Changes. International Review of Finance, 11(1), 1-17. http://dx.doi.org/10.1111/j.1468-2443.2010.01125.x

Yoon, Y., Canli, Z. G., \& Schwarz, N. (2006). The Effect of Corporate Social Responsibility (CSR) Activities on Companies with Bad Reputations. Journal of Consumer Psychology, 16(4), 377-390. http://dx.doi.org/10.1207/s15327663jcp1604_9

\section{Copyright Disclaimer}

Copyright for this article is retained by the author(s), with first publication rights granted to the journal.

This is an open-access article distributed under the terms and conditions of the Creative Commons Attribution license (http://creativecommons.org/licenses/by/3.0/). 